\title{
Effects of glazing and chitosan-based coating application on frozen salmon preservation during six-month storage in industrial freezing chambers
}

\author{
Nuno M.F. Soares ${ }^{\text {a, b}}$, Marina S.G. Oliveira ${ }^{\text {b }}$, António A. Vicente ${ }^{\text {b, * }}$ \\ ${ }^{a}$ Vanibru-Comércio de produtos Alimentares, Lda., Av. do Doutor Andrade Dias, 96, Ap. 2.2, 4470-575 Maia, Portugal \\ b CEB-Centre of Biological Engineering, Universidade do Minho, Campus de Gualtar, 4710-057 Braga, Portugal
}

\section{A R T I C L E I N F O}

\section{Article history:}

Received 5 June 2014

Received in revised form

31 October 2014

Accepted 2 December 2014

Available online 18 December 2014

\section{Keywords:}

Salmon

Quality

Freezing

Glazing

Chitosan

\begin{abstract}
A B S T R A C T
Freezing and glazing are techniques commonly used to reduce the incidence of fish deterioration processes. In order to find an alternative to complement freezing and replace water glazing, the present work aimed at evaluating the effect of water glazing and edible coatings of $0.5 \% \mathrm{w} / \mathrm{v}$ and $1.5 \% \mathrm{w} / \mathrm{v} \mathrm{chi}-$ tosan on quality parameters of frozen fish. Both types of coatings - water glazing and chitosan coatings - were applied directly on frozen Atlantic salmon (Salmo salar) and stored for 9 months at $-22{ }^{\circ} \mathrm{C}$. Several parameters such as coating/glazing loss, weight loss, drip loss, Total Viable Counts (TVC), Total Volatile Basic-Nitrogen (TVB-N), K-value, $\mathrm{pH}$ and color coordinates $L^{*} a^{*} b^{*}$ were periodically evaluated in order to compare glazing with the chitosan-based coatings and uncoated control samples. Samples coated with $1.5 \% \mathrm{w} / \mathrm{v}$ chitosan performed better in maintaining the color of the salmon and controlling microbial contamination of frozen and thawed samples.
\end{abstract}

() 2014 Elsevier Ltd. All rights reserved.

\section{Introduction}

The demand for food that promotes health and well-being has increased in recent years (FAO, 2012). The populations of many industrialized countries are becoming older, richer, more educated and more health conscious (FAO, 2012). Freezing is the main method of processing fish for human consumption and the most used to control and/or reduce biochemical changes that occur during storage (Fan et al., 2009; Kilincceker, Dogan, \& Kucukoner, 2009; Rodriguez-Turienzo et al., 2011; Sathivel, Liu, Huang, \& Prinyawiwatkul, 2007). However, there are reports of progressive loss of intrinsic and sensory quality of frozen fish during storage (Vanhaecke, Verbeke, \& eBrabander, 2010). In fact, if on one hand, the use of temperatures below $-12{ }^{\circ} \mathrm{C}$ inhibits microbial growth and slows down enzymatic activity (Jiang \& Lee, 2004 cited in Rodriguez-Turienzo et al., 2011), on the other hand, freezing is not able to completely inhibit microbial and chemical reactions, such as lipid oxidation, protein denaturation and surface dehydration (due to sublimation and recrystallization of ice crystals) leading to deterioration of fish quality during prolonged storage. These

\footnotetext{
* Corresponding author. Tel.: +351 253604419; fax: +351 253604429.

E-mail address: avicente@deb.uminho.pt (A.A. Vicente).
}

reactions result in off-flavors, rancidity, dehydration, weight loss, loss of juiciness, drip loss and toughening, as well as microbial spoilage and autolysis (Fan et al., 2009; Gonçalves \& Gindri Junior, 2009; Rodriguez-Turienzo et al., 2011 Sathivel et al., 2007).

The application of a thin layer of ice on the surface of the frozen products by spraying or dipping into a water bath is a common practice in frozen fish industry, in a process termed glazing (Gonçalves \& Gindri Junior, 2009; Vanhaecke et al., 2010). This technique aims at minimizing the impact of undesirable changes on the quality of frozen products during storage (Gonçalves \& Gindri Junior, 2009; Vanhaecke et al., 2010). This water glaze excludes air from the surface of the product, thus reducing the rate of oxidation and also serves as a protective barrier to temperature fluctuations, allowing the glaze to evaporate in the place of tissue water, when an increase of temperature occurs (Fossan \& Jacobsen, 2001 cited in Gonçalves \& Gindri Junior, 2009). New technologies are being used to ensure the conformity of frozen fish during storage trying to satisfy the growing demand for this product (Sathivel et al., 2007; Souza et al., 2010). Edible films and coatings have become a promising alternative to protect food products against mechanical damage, physical, chemical and microbiological activities (Falguera, Quintero, Jimenez, Munoz, \& Ibarz, 2011; Pinheiro et al., 2010). Chitosan is a natural amino-cationic hetero- 
polymer composed of $\beta-1.4$ D-glucosamine units, linked to N-acetylglucosamine residues, which can be obtained by chitin deacetylation. Chitosan attracts much attention in the food industry because it is non-toxic, bioactive (anti-microbial, anti-oxidant), biodegradable, biocompatible and has also a very interesting reactivity, selective permeability, polyelectrolytic action, adsorption capacity and ability to form gels and films, a consequence of its visco-elastic properties once in solution (Fan et al., 2009; Pinheiro et al., 2010; Sathivel et al., 2007).

Monitoring and controlling the quality of frozen fish is one of the fundamental worries of the seafood industry. Many parameters are involved in the definition of quality, including safety, nutritional and sensory properties, price, convenience and constancy, packaging color, availability and freshness (Ólafsdóttir et al., 1997; Souza et al., 2010). The change of one of these parameters affects largely the product acceptability by the consumers and consequently also its commercial value (Rodriguez-Turienzo et al., 2011). Freshness is one of the most important parameters for the quality of the final product (Ólafsdóttir et al., 1997).

\section{Materials and methods}

\subsection{Fish preparation}

Frozen and packaged Atlantic salmon (Salmo salar) fillet was obtained from a local company (Vanibru - Comércio de Produtos Alimentares, Braga, Portugal). After unpacking, the salmon fillets were cut into slices (samples) with the dimensions $10 \mathrm{~cm} \times 5 \mathrm{~cm} \times 2-3 \mathrm{~cm}$ (Fig. 1) and an average weight of $113.4 \pm 7.4 \mathrm{~g}$, using a vertical bone sawing machine (FK 32, BIZERBA, Germany). This process was carried out in a refrigerated $\left(5-8{ }^{\circ} \mathrm{C}\right)$ room to minimize heat uptake. For each treatment, salmon samples $(n=3)$ were individually packed in zip-lock polyethylene freezer bags and stored in an industrial freezing chamber maintained at $-21.4 \pm 1.6{ }^{\circ} \mathrm{C}$, for 9 months.

\subsection{Preparation of coating solutions}

Chitosan from Golden-shell Biochemical Co. Ltd. (China) with a 91\% degree of deacetylation was used. The coating solutions were prepared by dissolving chitosan $(0.5 \%$ and $1.5 \% \mathrm{w} / \mathrm{v})$ in a $1 \%(\mathrm{v} / \mathrm{v})$ lactic acid solution with agitation, using a magnetic stirrer, at a temperature of $45^{\circ} \mathrm{C}$, until complete dissolution.

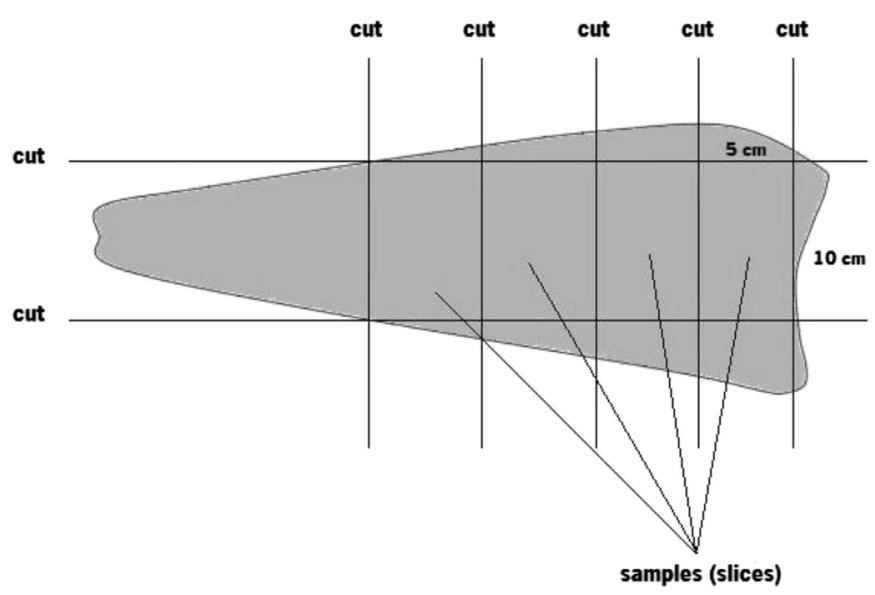

Fig. 1. Illustration of the salmon fillet, exemplifying the scheme of cuts used.

\subsection{Sample preparation}

\subsubsection{Samples coated with chitosan}

Frozen salmon samples at $-21.4 \pm 1.6^{\circ} \mathrm{C}$ were weighed $\left(W_{1}\right)$ and divided in two groups: one group of samples was immersed in a $0.5 \% \mathrm{w} / \mathrm{v}$ chitosan solution at $5.18 \pm 0.49{ }^{\circ} \mathrm{C}$ during $35 \mathrm{~s}$ and another group of samples was immersed in $1.5 \% \mathrm{w} / \mathrm{v}$ chitosan solution at $8.10 \pm 0.57{ }^{\circ} \mathrm{C}$ during $10 \mathrm{~s}$. The solution temperature was monitored by an infrared Pronto Plus thermometer (HANNA Instruments, HI765PW and HI99556-10, Romania). Samples were subsequently drained for $2 \mathrm{~min}$ and weighed again $\left(W_{2}\right)$. The temperatures and dipping times of the different coating solutions are different because they were adjusted to achieve a similar coating uptake in all samples. These experiments were performed in a pilot-scale glazing tank with the help of a stainless steel mesh, used to collect the samples from inside the tank in order to minimize the interference with the amount of coating applied. Following Equation (1), the coating uptake was calculated, where $W_{1}$ and $W_{2}$ indicate the weight of the salmon sample before and after the coating application, respectively. An average of $9.6 \pm 0.1 \%$ and $10.0 \pm 0.2 \%$ of coating uptake (wt\%) was obtained for chitosan solutions $(\mathrm{w} / \mathrm{v})$ of $0.5 \%$ and $1.5 \%$, respectively.

Coating uptake $(\%)=\frac{W_{2}-W_{1}}{W_{2}} \times 100$

\subsubsection{Samples glazed with water}

A similar process was followed for water glazed salmon samples. These samples were weighed $\left(W_{3}\right)$, dipped in water at $0.28 \pm 0.08{ }^{\circ} \mathrm{C}$ for $40 \mathrm{~s}$, drained for $1 \mathrm{~min}$ and weighted again $\left(W_{4}\right)$. Glazing uptake was calculated using Equation (2), where $W_{3}$ and $W_{4}$ indicate the weight before and after glazing is applied in the samples, respectively. An average of glazing uptake of $8.4 \pm 0.3 \%$ was obtained.

Glazing uptake $(\%)=\frac{W_{4}-W_{3}}{W_{4}} \times 100$

\subsubsection{Control samples}

Samples from the control group were left untreated. These noncoated samples were used for comparison with the remaining groups of samples.

\subsection{Samples storage and transport}

All salmon samples were individually packed in ziplock polyethylene freezer bags, inside corrugated boxes, and stored in an industrial freezing chamber maintained at $-21.4 \pm 1.6{ }^{\circ} \mathrm{C}$, for 6 months. This temperature was monitored using a data logger (DS7922 1Wire $^{\circledR}$ Thermochrom ${ }^{\circledR}$ iButton $^{\circledR}$, Dallas Semiconductor Inc., U.S.A.). All analyses were done in triplicate.

\subsection{Samples analyses}

\subsubsection{Coating loss}

After the storage period, coated samples were weighed again $\left(W_{5}\right)$ and the coating loss was calculated using Equation (3).

Coating $\operatorname{loss}(\%)=\frac{W_{5}-W_{2}}{W_{2}-W_{1}} \times 100$ 


\subsubsection{Glazing loss}

After the storage period, glazed samples were weighed again $\left(W_{6}\right)$ and the glazing loss was calculated using Equation (4).

Glazing loss $(\%)=\frac{W_{6}-W_{4}}{W_{4}-W_{3}} \times 100$

\subsubsection{Weight loss}

The control samples left untreated do not have any coating. In this case, the uncoated samples were initially weighed $\left(W_{7}\right)$ and after the storage period were weighed again $\left(W_{8}\right)$ and the weight loss was calculated with Equation (5):

Weight loss $(\%)=\frac{W_{8}-W_{7}}{W_{8}} \times 100$

\subsubsection{Drip loss}

To calculate the drip loss, all frozen samples were removed from the freezer, kept for $22 \mathrm{~h}$ in the refrigerator at $5{ }^{\circ} \mathrm{C}$, removed from the zip-lock polyethylene bags and placed on a rack for 2 min to release drip, after which thawed samples were weighed. Drip loss was calculated using Equation (6), were $W_{9}$ indicates the weight of frozen samples without coating/glazing and before being placed in the refrigerator and $W_{10}$ indicates the weight of thawed samples (Sathivel et al., 2007).

$\operatorname{Drip} \operatorname{loss}(\%)=\frac{W_{9}-W_{100}}{W_{9}} \times 100$

\subsubsection{Determination of TVC}

Total Aerobic Plate counts were estimated by the procedure based on the BS EN ISO 4833:2003 Standard Protocol. The Total Viable Counts (TVC) were estimated for frozen $\left(-20^{\circ} \mathrm{C}\right)$ and thawed samples $\left(5.9{ }^{\circ} \mathrm{C}\right)$.

\subsubsection{Determination of TVB-N}

The value of TVB-N was determined by the method of Conway as described in NP 2930:2009.

\subsubsection{Determination of K-value}

K-value was determined according to the method of Ryder (1985) as described by Souza et al. (2010). A 5 g sample was homogenized (BECKEN coffee grinder, Worten, Portugal) with $25 \mathrm{~mL}$ of chilled $0.6 \mathrm{~mol} / \mathrm{L}$ perchloric acid $\left(\mathrm{HClO}_{4}\right)$ at $0{ }^{\circ} \mathrm{C}$ for $1 \mathrm{~min}$. The homogenate was centrifuged (EBA 20, Hettich zentrifugen, Germany) at $3000 \times \mathrm{g}(6000 \mathrm{rpm})$ for $10 \mathrm{~min}$. Using a $\mathrm{pH}$ meter, $10 \mathrm{~mL}$ of the supernatant was adjusted to $\mathrm{pH} 6.5-6.8$ with $1 \mathrm{~mol} / \mathrm{L}$ potassium hydroxide (KOH) (Metrohm $620 \mathrm{pH}$ meter, Switzerland). After standing in flaked ice for $30 \mathrm{~min}$, the potassium perchlorate that precipitated was removed by filtration using Whatman $n^{\circ} 1$ filter paper. The filtrate was diluted to $20 \mathrm{~mL}$ with Milli-Q purified distilled water, passed through a $0.20 \mu \mathrm{m}$ Fioroni membrane, and stored at $-80{ }^{\circ} \mathrm{C}$ until being subsequently analyzed by High Performance Liquid Chromatography (HPLC). Twenty microliter aliquots of all samples were analyzed by HPLC (Hitachi HighTechnologies Corporation chromatograph, VWR, Tokyo, Japan)) equipped with a Organizer (Elite Lachrom), Pump (Elite Lachrom L2130), UV-Vis detector (Elite Lachrom L-2420) at $254 \mathrm{~nm}$, Autosampler (Elite Lachrom L-2200) and Column oven (Elite Lachrom L2300) with a Purospher ${ }^{\circledR}$ Star RP-18e (endcapped particles, $5 \mu \mathrm{m}$ particle size, LichroCART ${ }^{\circledR}$ 250-4 HPLC Cartridge, ART.
1.50252.0001, Sorbent Lot Hx947476, Merck, Germany) column. Separation of the nucleotide products was achieved using a mobile phase of $0.04 \mathrm{~mol} / \mathrm{L} \mathrm{KH}_{2} \mathrm{PO}_{4}$ and $0.06 \mathrm{~mol} / \mathrm{L} \mathrm{K}_{2} \mathrm{HPO}_{4}$ dissolved at a 1:1 ratio in Milli-Q purified distilled water, at a flow rate of $1 \mathrm{~mL} /$ min. The peaks obtained from fish muscle extracts were identified and quantified through standard solution curves. ATP breakdown products comprising adenosine triphosphate (ATP), adenosine diphosphate (ADP), adenosine monophosphate (AMP), inosine monophosphate (IMP), inosine ( $\mathrm{HxR}$ ), and hypoxanthine (Hx) were measured, and the K-value was calculated using Equation (7) described by Saito, Arai, and Matsuyoshi (1959):

$$
\begin{aligned}
K-\operatorname{value}(\%)= & \frac{[H x]+[H x R]}{([A T P]+[A D P]+[A M P]+[I M P]+[H x]+[H x R])} \\
& \times 100
\end{aligned}
$$

\subsubsection{Determination of $p H$-value}

After removing the coating/glazing with a knife in order to prevent changes in the samples, a $5 \mathrm{~g}$ portion of each sample was homogenized with $50 \mathrm{~mL}$ of distilled water in a mixer (BECKEN coffee grinder, Worten, Portugal) for $30 \mathrm{~s}$ and the $\mathrm{pH}$ value of the suspension was measured using a pH meter (Metrohm $620 \mathrm{pH}$ meter, Switzerland).

\subsubsection{Determination of color parameters}

The instrumental measurement of salmon color was performed using a colorimeter (CHROMA METER CR-400/410, AQUATEKNICA, SA, Konica Minolta, Japan). Results were expressed using the CIE $L^{*} a^{*} b^{*}$ system. The values obtained for the first trial served as a reference standard. These values were discounted to the values of the following tests to calculate $\Delta E^{*} a b$ (Equation (8)). The samples, with approximately $1 \mathrm{~cm}$ of thickness, were evaluated at six different points, 3 points on the right side and 3 points on the left side, to obtain an average color value within the same sample. The equipment was calibrated using the white calibration plate available from the equipment (Fig. 2). Salmon samples were stored in a controlled temperature chamber at $-15.8 \pm 1.7{ }^{\circ} \mathrm{C}$ and they were taken at different times points for evaluation. This temperature was

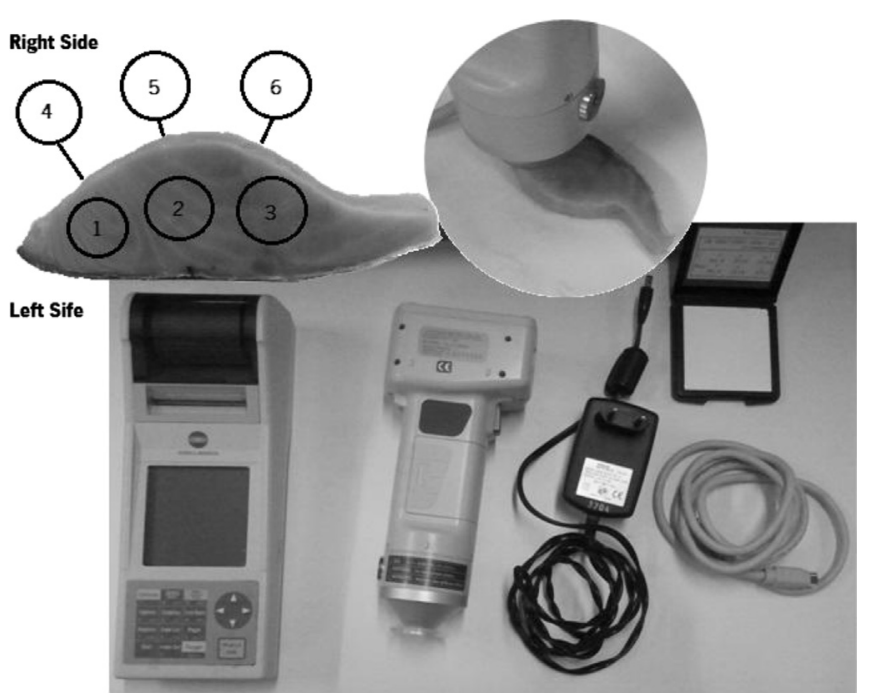

Fig. 2. Illustration of the methodology and equipment used in the measurement of the color of salmon. 
monitored using a data logger (DS7922 1-Wire ${ }^{\circledR}$ Thermochrom ${ }^{\circledR}$ iButton $^{\circledR}$, Dallas Semiconductor Inc., U.S.A.).

$\Delta E^{*} a b=\left[(\Delta L)^{2}+(\Delta a)^{2}+(\Delta b)^{2}\right]^{1 / 2}$

\subsubsection{Statistical analyses}

All experiments were performed in triplicate. The mean values of those 3 independent determinations were calculated for each treatment at every moment. The statistical significance of differences among treatment means was evaluated by analysis of variance (ANOVA) followed by the Tukey test with significance at $p<0.05$. Data were evaluated statistically using the software STATISTICA version 7.0 (StatSoft Inc. 2004).

\section{Results and discussion}

\subsection{Coating loss}

The effect of chitosan coatings, water glazing and storage time on the coating/glazing loss of salmon samples during storage at $-22{ }^{\circ} \mathrm{C}$ is shown in Fig. 3. The application of both coatings (chitosan coating and water glazing) presented no statistically significant effect in the initial coating/glazing loss values. Although stable in an initial period, after 13 and 39 days of storage the samples coated with $0.5 \%$ chitosan showed a tendency to have smaller coating loss values than glazed samples. This trend was clear in the subsequent period, after 68 and 125 days of storage, when this difference becomes significantly different. After 182 days of storage, is possible to detect a more pronounced effect of the $0.5 \%$ chitosan coating in the coating loss when compared with the samples glazed with water, although no statistically significant difference was observed. Samples coated with $1.5 \%$ chitosan were also tested but only on two occasions: 68 days and 182 days of storage. These samples appear to loose less coating than glazed samples, but there are no statistically significant differences between the two treatments. The same tendency did not occur when comparing samples coated with $1.5 \%$ chitosan with samples coated with $0.5 \%$ chitosan, since the former seem to suffer an equal or greater coating loss. In the last moment, after 257 days of storage, the glazed samples show a higher coating loss when compared with the other moments and the other coatings, while the samples coated with $0.5 \%$ of chitosan remain stable. At this moment,

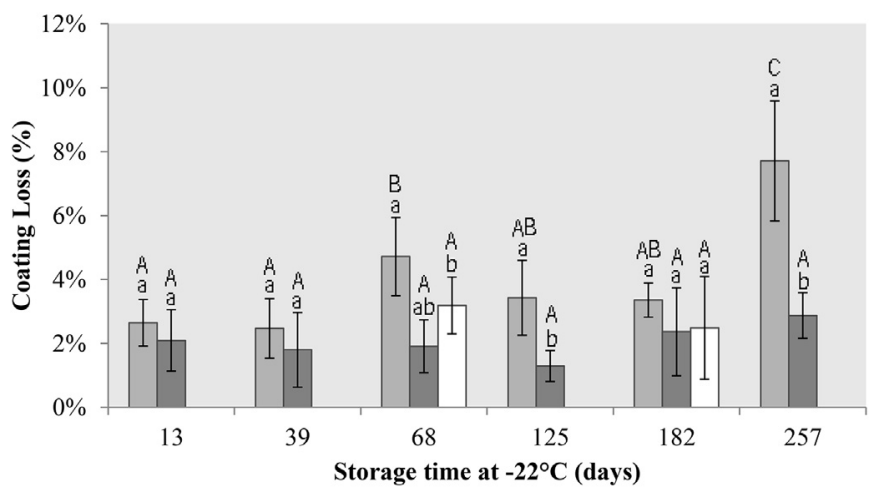

Fig. 3. Coating Loss (\%) for salmon samples glazed with water ( $\square$ Q0) and coated with $0.5 \%$ chitosan ( $\square$ Q5) and $1.5 \%$ chitosan ( $\square$ Q15) during 257 days of storage at $-22{ }^{\circ} \mathrm{C}$. Each bar represents the mean \pm standard deviation of three replications. Different small letters in the same day and different capital letters in bars with the same color indicate a statistically significant difference (Tukey test, $p<0.05$ ). although the standard deviation is higher for the glazed samples, it is even more evident the greatest coating loss of the glazed samples comparing with that of samples coated with $0.5 \%$ of chitosan.

According to Gonçalves and Gindri Junior (2009), the weight loss by dehydration during freezing and storage can be reduced by two methods: covering the surface with packaging material or surrounding the product with a thin layer of ice. Jacobsen and Fossan (2001) add that if the product is subject to inadequate cold storage, glaze will evaporate instead of tissue water itself, thus protecting the product, an idea also supported by Kilincceker et al. (2009). Also, Kester \& Fennema (1986), cited by Sathivel et al. (2007) and Rodriguez-Turienzo et al. (2011), reported that chitosan coatings may function as moisture-sacrificing agents instead of moisture barriers, thus moisture loss from the product could be delayed until the moisture contained within the chitosan coating had been evaporated. That is, while coatings loose their water by sublimation during storage, they prevent losses of food moisture. A study performed by Soares, Mendes, and Vicente (2013) reports a higher coating loss of frozen salmon samples during storage at $-5{ }^{\circ} \mathrm{C}$ when compared to losses at lower temperatures. The different storage temperatures may explain the different results, since at $-5{ }^{\circ} \mathrm{C}$ ice is closer to its melting point and more liquid water is available than at $-18{ }^{\circ} \mathrm{C}$. The apparent stability of the coating loss values for the different coatings indicate that an adequate freezing temperature $\left(<-18{ }^{\circ} \mathrm{C}\right)$ can be effective in reducing coating loss during storage, thus increasing fish protection.

\subsection{Weight loss}

The weight loss of salmon samples during storage at $-22{ }^{\circ} \mathrm{C}$ is shown in Fig. 4. These values showed no significant differences throughout storage, except at the last moment, where the weight loss value was statistically different from the first two initial moments. Despite being very small, these values show an increasing tendency along the entire storage period, starting at $0.08 \pm 0.04 \%$ and ending at $0.20 \pm 0.07 \%$. Johnston, Nicholson, Roger, and Stroud (1994) states that weight loss due to dehydration in a freezer depends on the type of freezer, freezing time, type of product, air velocity and freezer operating conditions. These reduced values might be explained by a well controlled storage temperature, since the temperature profile from the industrial chamber used showed an amplitude of temperature values of less than $2{ }^{\circ} \mathrm{C}$ and due to the fact that all samples, including the control samples without coating,

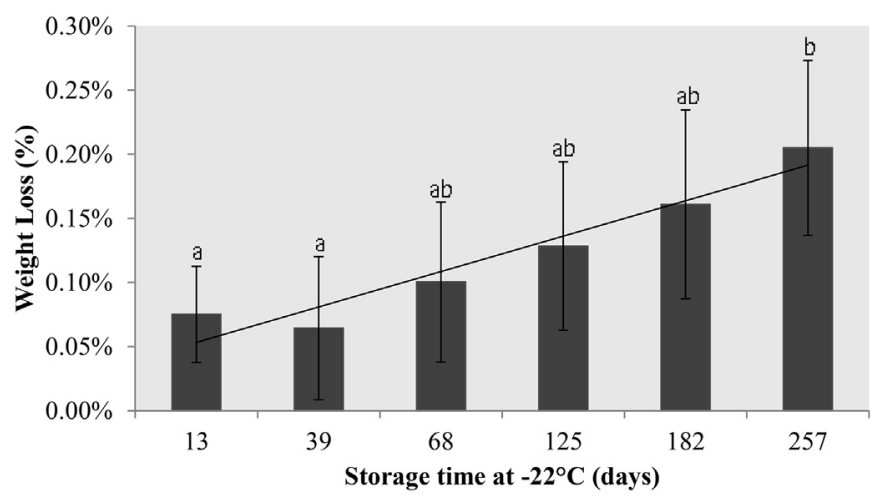

Fig. 4. Weight Loss (\%) of uncoated salmon samples from the control group ( $\square$ QS) during 257 days of storage at $-22{ }^{\circ} \mathrm{C}$. Each bar represents the mean \pm standard deviation of three replications. Different letters indicate a statistically significant difference (Tukey test, $p<0.05$ ). 
are stored in polyethylene bags, inside corrugated boxes, which also act as protection.

\subsection{Drip loss}

The drip loss of salmon samples during storage at $-22{ }^{\circ} \mathrm{C}$ is shown in Fig. 5. The different coatings did not appear to interfere in a significant way with the drip loss, since the values do not show statistically significant differences in this case. The initial drip loss value for the control sample (without coating) was $1.7 \pm 0.5 \%$ and the values for these control samples increased throughout storage. Except for 126 days of storage, all coatings also increased the amount of drip loss. As a whole, drip loss followed a growing trend during storage, increasing significantly (to almost twice) for all samples in the last sampling period. According to Fellows (2000), temperature fluctuation has a cumulative effect on food quality. During thawing, in samples subjected to slow freezing or recrystallization, cells do not regain their original shape and turgidity because the growing ice crystals deform and rupture adjacent cell walls, increasing the release of cell constituents (water-soluble nutrients) to form drip losses.

\subsection{TVC}

The total viable counts (TVC) for frozen salmon samples $\left(-20^{\circ} \mathrm{C}\right)$ during 250 days of storage at $-22{ }^{\circ} \mathrm{C}$ are presented in Table 1 . Data show that uncoated samples display values generally greater than glazed samples. The samples coated with chitosan showed favorable values of TVC when compared with uncoated and glazed samples. While samples coated with $1.5 \%$ chitosan constantly show values below 10 , the same did not happen with samples coated with $0.5 \%$ chitosan. Both coatings - water and chitosan - acted in the reduction and maintenance of the microbial load of the frozen samples. However, the samples coated with chitosan showed the most promising results in microbial protection of frozen fishery products, especially those coated with 1.5\% chitosan. The ability of chitosan coatings to reduce, inhibit or prevent growth of microorganisms on food surfaces has been referenced by several authors, including Falguera et al. (2011) and Pereira, Souza, Cerqueira, Teixeira, and Vicente (2010). As expected freezing also has been effective since all TVC values, including for uncoated samples, are below the acceptable threshold around

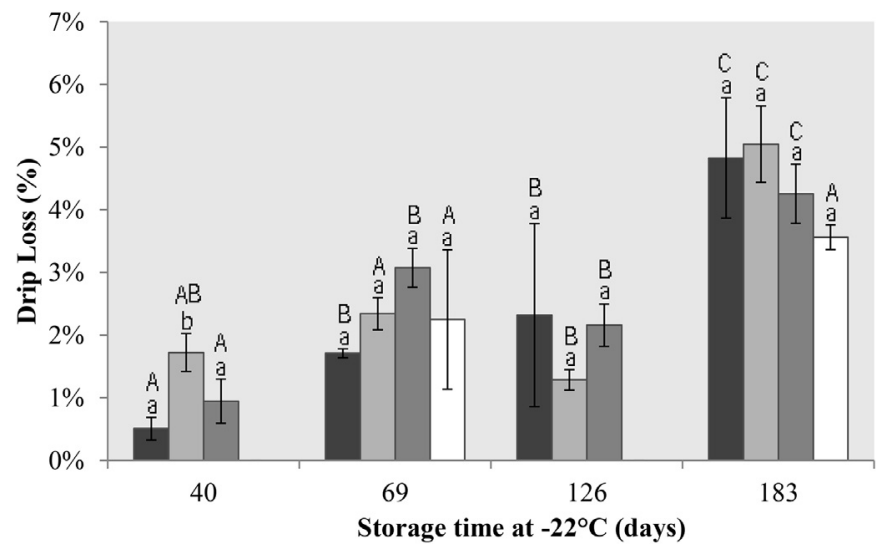

Fig. 5. Drip Loss (\%) of salmon samples from the control group ( $\square$ QS), glazed with water ( $\square$ Q0) and coated with $0.5 \%$ chitosan ( $\square$ Q5) and $1.5 \%$ chitosan ( $\square$ Q15) during 183 days of storage at $-22{ }^{\circ} \mathrm{C}$. Each bar represents the mean \pm standard deviation of three replications. Different small letters in the same day and different capital letters in bars with the same color indicate a statistically significant difference (Tukey test, $p<0.05$ ).

\section{Table 1}

Total viable counts (TVC) values for frozen salmon samples $\left(-20^{\circ} \mathrm{C}\right)$ from the control group ( $\square$ QS), glazed with water $(\square$ Q0) and coated with $0.5 \%$ chitosan ( $\square$ Q5) and $1.5 \%$ chitosan ( $\square$ Q15) after 250 days of storage at $-22{ }^{\circ} \mathrm{C}$; standard deviation corresponds to three replications.

\begin{tabular}{|c|c|c|c|c|c|c|}
\hline $\begin{array}{c}\text { TVC } \\
\left(-20^{\circ} \mathrm{C}\right)\end{array}$ & $\begin{array}{c}\text { Storage Time } \\
\text { (days) }\end{array}$ & $\begin{array}{c}\text { Sample } 1 \\
(\mathrm{CFU} / \mathrm{g})\end{array}$ & $\begin{array}{l}\text { Sample } 2 \\
\text { (CFU/g) }\end{array}$ & $\begin{array}{c}\text { Sample } 3 \\
\text { (CFU/g) }\end{array}$ & $\begin{array}{c}\text { Mean } \\
(\mathrm{CFU} / \mathrm{g})\end{array}$ & SD \\
\hline \multirow{7}{*}{ QS } & 0 & $6.00 \mathrm{E}+03$ & $5.80 \mathrm{E}+02$ & $1.60 \mathrm{E}+03$ & $2.73 E+03$ & $2.88 \mathrm{E}+03$ \\
\hline & 13 & $3.60 \mathrm{E}+02$ & $1.50 \mathrm{E}+02$ & $5.80 \mathrm{E}+02$ & $3.63 \mathrm{E}+02$ & $2.15 \mathrm{E}+02$ \\
\hline & 40 & $1.00 \mathrm{E}+03$ & $1.70 \mathrm{E}+03$ & $5.40 \mathrm{E}+02$ & $1.08 \mathrm{E}+03$ & $5.84 \mathrm{E}+02$ \\
\hline & 62 & $<10$ & $<10$ & $<10$ & $<10$ & - \\
\hline & 118 & $5.10 \mathrm{E}+02$ & $2.70 \mathrm{E}+02$ & $6.40 \mathrm{E}+02$ & $4.73 \mathrm{E}+02$ & $1.88 \mathrm{E}+02$ \\
\hline & 181 & $1.10 \mathrm{E}+03$ & $1.80 \mathrm{E}+03$ & $6.00 \mathrm{E}+03$ & $2.97 \mathrm{E}+03$ & $2.65 \mathrm{E}+03$ \\
\hline & 250 & $1.70 \mathrm{E}+03$ & $8.50 \mathrm{E}+02$ & $1.30 \mathrm{E}+05$ & $4.42 \mathrm{E}+04$ & $7.43 \mathrm{E}+04$ \\
\hline \multirow{6}{*}{ Q0 } & 13 & $7.90 \mathrm{E}+02$ & $7.20 \mathrm{E}+02$ & $5.60 \mathrm{E}+02$ & $6.90 \mathrm{E}+02$ & $1.18 \mathrm{E}+02$ \\
\hline & 40 & $5.80 \mathrm{E}+02$ & $1.20 \mathrm{E}+03$ & $3.50 \mathrm{E}+02$ & $7.10 \mathrm{E}+02$ & $4.40 \mathrm{E}+02$ \\
\hline & 62 & $3.50 \mathrm{E}+02$ & $3.30 \mathrm{E}+02$ & $1.20 \mathrm{E}+02$ & $2.67 \mathrm{E}+02$ & $1.27 \mathrm{E}+02$ \\
\hline & 118 & $4.80 \mathrm{E}+02$ & $2.10 \mathrm{E}+02$ & $7.80 \mathrm{E}+02$ & $4.90 \mathrm{E}+02$ & $2.85 \mathrm{E}+02$ \\
\hline & 181 & $9.60 \mathrm{E}+04$ & $7.00 \mathrm{E}+03$ & $6.60 \mathrm{E}+03$ & $3.65 \mathrm{E}+04$ & $5.15 \mathrm{E}+04$ \\
\hline & 250 & $1.10 \mathrm{E}+04$ & $7.00 \mathrm{E}+03$ & $3.30 \mathrm{E}+03$ & $7.10 \mathrm{E}+03$ & $3.85 \mathrm{E}+03$ \\
\hline \multirow{6}{*}{ Q5 } & 13 & $<10$ & $<10$ & $<10$ & $<10$ & - \\
\hline & 40 & $<10$ & $1.50 \mathrm{E}+02$ & $<10$ & - & - \\
\hline & 62 & $<10$ & $<10$ & $<10$ & $<10$ & - \\
\hline & 118 & $2.10 \mathrm{E}+02$ & $<10$ & $<10$ & - & - \\
\hline & 181 & $2.60 \mathrm{E}+02$ & $<10$ & $<10$ & - & - \\
\hline & 250 & $4.40 \mathrm{E}+02$ & $4.00 \mathrm{E}+02$ & $2.40 \mathrm{E}+02$ & $3.60 \mathrm{E}+02$ & $1.06 \mathrm{E}+02$ \\
\hline \multirow{2}{*}{ Q15 } & 62 & $<10$ & $<10$ & $<10$ & $<10$ & - \\
\hline & 181 & $<10$ & $<10$ & $<10$ & $<10$ & - \\
\hline
\end{tabular}

$10 \mathrm{E}+07-10 \mathrm{E}+08 \mathrm{CFU} / \mathrm{g}$, which lies at the point of sensory rejection (Ólafscóttir et al., 1997) and never exceeded the microbiological limit of 5E + 05 CFU/g recommended by ICMSF (1986) for frozen fish of good quality.

The total viable counts (TVC) values for the unfrozen salmon samples $\left(5.9^{\circ} \mathrm{C}\right)$ after $24 \mathrm{~h}$, during 250 days of storage at $-22^{\circ} \mathrm{C}$ are presented in Table 2 . The same trend observed for frozen salmon could be confirmed. Again, all values are below the threshold of rejection and uncoated samples have higher TVC values than glazed and coated samples. The coated samples showed lower TVC values

\section{Table 2}

Total viable counts (TVC) values for refrigerated salmon samples $\left(5.9^{\circ} \mathrm{C}\right)$ from the control group ( $\square \mathrm{QS}$ ), glazed with water $(\square \mathrm{Q} 0)$ and coated with $0.5 \%$ chitosan ( $\square \mathrm{Q} 5)$ and $1.5 \%$ chitosan ( $\square$ Q15) after 250 days of storage at $-22{ }^{\circ} \mathrm{C}$; standard deviation corresponds to three replications.

\begin{tabular}{|c|c|c|c|c|c|c|}
\hline $\begin{array}{c}\text { TVC } \\
\left(5.9^{\circ} \mathrm{C}\right)\end{array}$ & $\begin{array}{l}\text { Storage Time } \\
\text { (days) }\end{array}$ & $\begin{array}{c}\text { Sample } 1 \\
\text { (CFU/g) }\end{array}$ & $\begin{array}{c}\text { Sample } 2 \\
\text { (CFU/g) }\end{array}$ & $\begin{array}{c}\text { Sample } 3 \\
\text { (CFU/g) }\end{array}$ & $\begin{array}{c}\text { Mean } \\
(\text { CFU/g) }\end{array}$ & SD \\
\hline \multirow{7}{*}{ QS } & 0 & $7.30 \mathrm{E}+03$ & $2.00 \mathrm{E}+03$ & $3.30 \mathrm{E}+03$ & $4.20 \mathrm{E}+03$ & $2.76 \mathrm{E}+03$ \\
\hline & 13 & $2.80 \mathrm{E}+03$ & $2.20 \mathrm{E}+02$ & $1.50 \mathrm{E}+03$ & $1.51 \mathrm{E}+03$ & $1.29 \mathrm{E}+03$ \\
\hline & 40 & $4.50 \mathrm{E}+03$ & $9.50 \mathrm{E}+03$ & $7.10 \mathrm{E}+03$ & $7.03 E+03$ & $2.50 \mathrm{E}+03$ \\
\hline & 62 & $1.50 \mathrm{E}+02$ & $1.40 \mathrm{E}+02$ & $1.00 \mathrm{E}+02$ & $1.30 \mathrm{E}+02$ & $2.65 \mathrm{E}+01$ \\
\hline & 118 & $2.80 \mathrm{E}+05$ & $3.00 \mathrm{E}+02$ & $1.20 \mathrm{E}+03$ & $9.38 \mathrm{E}+04$ & $1.61 \mathrm{E}+05$ \\
\hline & 181 & $1.10 \mathrm{E}+05$ & $3.70 \mathrm{E}+03$ & $1.00 \mathrm{E}+04$ & $4.12 \mathrm{E}+04$ & $5.96 \mathrm{E}+04$ \\
\hline & 250 & $1.60 \mathrm{E}+03$ & $1.40 \mathrm{E}+03$ & $7.10 \mathrm{E}+05$ & $2.38 \mathrm{E}+05$ & $4.09 \mathrm{E}+05$ \\
\hline \multirow{6}{*}{ Q0 } & 13 & $1.10 \mathrm{E}+03$ & $1.10 \mathrm{E}+03$ & $1.40 \mathrm{E}+03$ & $1.20 \mathrm{E}+03$ & $1.73 \mathrm{E}+02$ \\
\hline & 40 & $1.60 \mathrm{E}+03$ & $1.40 \mathrm{E}+03$ & $8.70 \mathrm{E}+02$ & $1.29 \mathrm{E}+03$ & $3.77 \mathrm{E}+02$ \\
\hline & 62 & $7.10 \mathrm{E}+02$ & $3.70 \mathrm{E}+02$ & $1.40 \mathrm{E}+03$ & $8.27 \mathrm{E}+02$ & $5.25 \mathrm{E}+02$ \\
\hline & 118 & $1.20 \mathrm{E}+03$ & $3.20 \mathrm{E}+03$ & $3.70 \mathrm{E}+03$ & $2.70 \mathrm{E}+03$ & $1.32 \mathrm{E}+03$ \\
\hline & 181 & $8.60 \mathrm{E}+04$ & $7.60 \mathrm{E}+03$ & $8.50 \mathrm{E}+03$ & $3.40 \mathrm{E}+04$ & $4.50 \mathrm{E}+04$ \\
\hline & 250 & $1.00 \mathrm{E}+04$ & $1.70 \mathrm{E}+04$ & $5.20 \mathrm{E}+03$ & $1.07 \mathrm{E}+04$ & $5.93 \mathrm{E}+03$ \\
\hline \multirow{6}{*}{ Q5 } & 13 & $<10$ & $1.00 \mathrm{E}+02$ & $2.50 \mathrm{E}+02$ & - & - \\
\hline & 40 & $<10$ & $2.40 \mathrm{E}+02$ & $1.50 \mathrm{E}+02$ & - & - \\
\hline & 62 & $<10$ & $<10$ & $<10$ & - & - \\
\hline & 118 & $3.20 \mathrm{E}+02$ & $3.00 \mathrm{E}+02$ & $<10$ & - & - \\
\hline & 181 & $1.40 \mathrm{E}+03$ & $1.50 \mathrm{E}+02$ & $8.40 \mathrm{E}+02$ & $7.97 \mathrm{E}+02$ & $6.26 \mathrm{E}+02$ \\
\hline & 250 & $8.50 \mathrm{E}+02$ & $9.30 \mathrm{E}+02$ & $4.10 \mathrm{E}+02$ & $7.30 \mathrm{E}+02$ & $2.80 \mathrm{E}+02$ \\
\hline \multirow{2}{*}{ Q15 } & 62 & $<10$ & $<10$ & $<10$ & - & - \\
\hline & 181 & $<10$ & $<10$ & $<10$ & - & - \\
\hline
\end{tabular}


than glazed samples. However, all coatings, especially chitosan coatings, were effective in protecting the thawed samples at refrigeration temperatures. Coatings with 1.5\% chitosan again showed consistent protection of the samples, this time thawed, maintaining the TVC below 10 in all samples, throughout the entire storage period. During simulation of thawing conditions of fish at consumers' homes $1.5 \%$ chitosan coatings have thus demonstrated to be effective in protecting thawed samples at refrigeration temperatures.

\section{5. $T V B-N$}

TVB-N is one of the parameters used to evaluated fish freshness, monitor spoilage and assess its quality, through measurements of characteristic volatile compounds (Ólafsdóttir et al., 1997).

The TVB-N values for frozen salmon samples during storage are presented in Fig. 6. The initial TVB-N value for the uncoated sample was $6.96 \pm 1.01 \mathrm{mg}$ nitrogen $/ 100 \mathrm{~g}$ sample. In the first moments, after 13 and also after 69 days, the TVB-N values suffered no great changes, decreasing just slightly. However, all the samples increased at the last moment, after 188 days of storage. The same is true for the samples coated with $1.5 \%$ chitosan. In general, the TVB$\mathrm{N}$ values are quite similar for all the coatings, contributing to the lack of statistically significant differences. Such lack of significant differences did not allow the detection of any particular effect of the different coatings. These low values, far below the $35 \mathrm{mg}$ nitrogen/ $100 \mathrm{~g}$ fish established as limit of acceptability of salmon by Directive 95/149/EC, indicate a good state of fish preservation. It is also important to note that the storage temperature was a relevant factor, being able to inhibit changes in volatile compounds and consequently maintaining the TVB-N values stable, during 188 days of frozen storage.

\section{6. $K$-value}

The K-value is used as an index for estimation of fish freshness and it is defined as the ratio of the sum of inosine and hypoxanthine concentrations to the total concentration of ATP metabolites (Souza et al., 2010).

The K-values for frozen salmon samples, during 258 days of storage, are presented in Fig. 7. From the data analysis it is not possible to draw any conclusions about the effect of coatings and

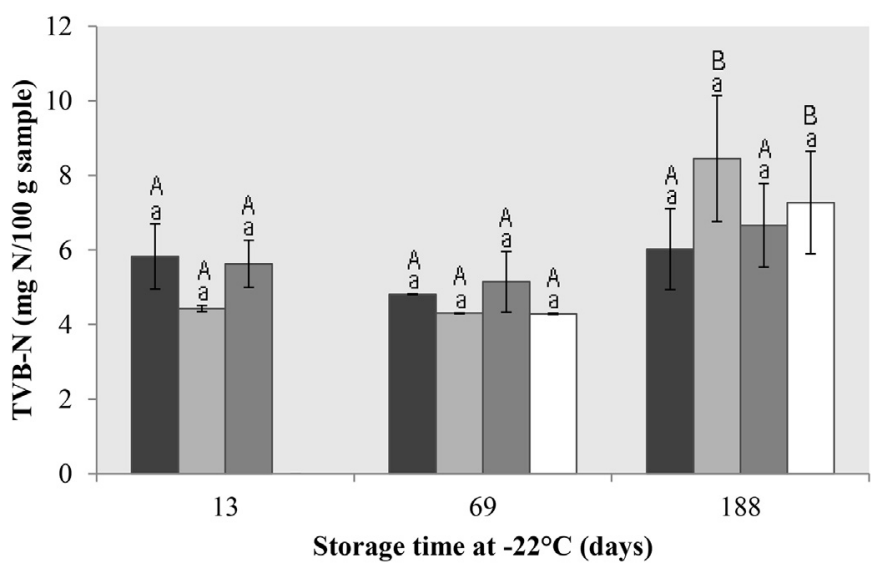

Fig. 6. Total volatile basic nitrogen (TVB-N) values for salmon samples from the control group ( $\square$ QS), glazed with water $(\square$ Q0) and coated with $0.5 \%$ chitosan ( $\square$ Q5) and $1.5 \%$ chitosan ( $\square \mathrm{Q} 15$ ) during 188 days of storage at $-22^{\circ} \mathrm{C}$. Each bar represents the mean \pm standard deviation of three replications. Different small letters in the same day and different capital letters in bars with the same color indicate a statistically significant difference (Tukey test, $p<0.05$ ).

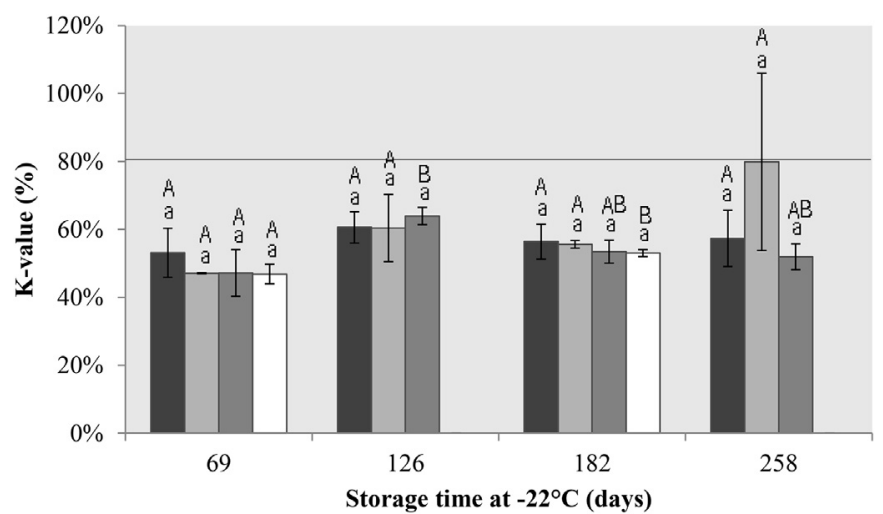

Fig. 7. K-values for salmon samples from the control group ( $\square$ QS), glazed with water $(\square$ Q0) and coated with $0.5 \%$ chitosan ( $\square$ Q5) and 1.5\% chitosan ( $\square$ Q15) during 258 days of storage at $-22{ }^{\circ} \mathrm{C}$. Each bar represents the mean \pm standard deviation of three replications. Different small letters in the same day and different capital letters in bars with the same color indicate a statistically significant difference (Tukey test, $p<0.05$ ).

glaze in ATP degradation of salmon samples, since the results are very similar and no statistically significant difference was detected. The majority of K-values are lower, never exceeding 67\%. However, it was expected that the samples could exhibit high K-value results, since they came from a processed product from aquaculture. According to Erikson, Beyer, and Sigholt (1997), it seems reasonable to propose an upper K-value limit of $70-80 \%$ for good-quality Atlantic salmon (ice stored), and tentatively, lower than $40-50 \%$ for excellent quality. So it can be stated that the salmon samples indicate a fish of good quality, since they are below the maximum rejection limit of $80 \%$. Again the storage temperature emerges as an important factor in the stabilization of K-values. According to the study conducted by Soares et al. (2013), for 14 weeks of storage at $-5^{\circ} \mathrm{C}$, the K-values showed an increasing trend, which did not happen in this experiment at $-22{ }^{\circ} \mathrm{C}$, where the K-values returned quite similar.

\section{7. $p H$ value}

$\mathrm{pH}$ values during frozen storage are represented in Fig. 8. The initial $\mathrm{pH}$ of the uncoated sample was found to be $6.43 \pm 0.05$. After 13 days, the $\mathrm{pH}$ of all samples increased for the uncoated, glazed and $0.5 \%$ chitosan coated samples, respectively. Throughout the remaining storage time, the $\mathrm{pH}$ values show a significant

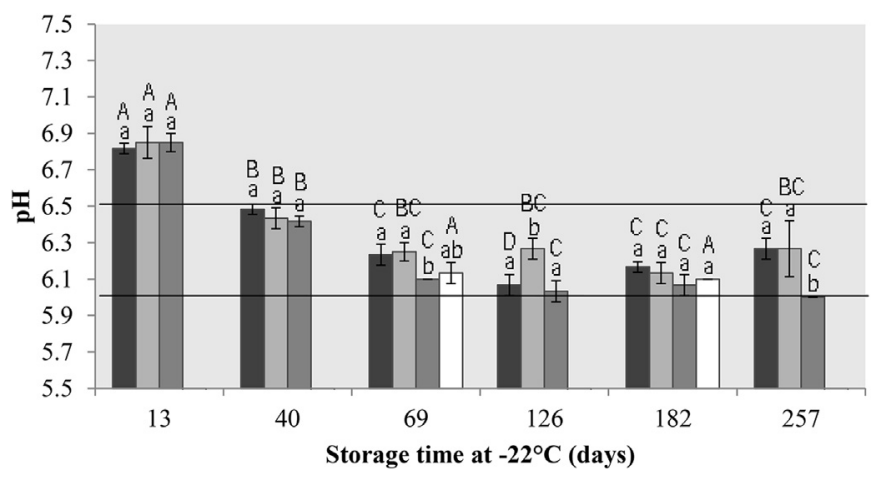

Fig. 8. pH values for salmon samples from the control group ( $\square \mathrm{QS}$ ), glazed with water ( $\square$ Q0) and coated with $0.5 \%$ chitosan ( $\square$ Q5) and 1.5\% chitosan ( $\square$ Q15) during 257 days of storage at $-22{ }^{\circ} \mathrm{C}$. Each bar represents the mean \pm standard deviation of three replications. Different small letters in the same day and different capital letters in bars with the same color indicate a statistically significant difference (Tukey test, $p<0.05$ ). 
decreasing trend, which is supported by the results of the statistical analysis (capital letters). However, at the last moment, after 257 days of storage, the $\mathrm{pH}$ of the samples coated with $0.5 \%$ chitosan was significantly lower than the values of the uncoated and glazed samples. This may indicate that at long-term, the chitosan coating will assist in the stability maintenance of the $\mathrm{pH}$ value. According to Rodriguez-Turienzo et al. (2011), freezing causes changes in pH values of fish muscle towards higher acidity, probably due to the increase in concentration of substances in the water that remains unfrozen and modifies the acid-base equilibrium. The mean $\mathrm{pH}$ values of all the samples were not higher than the limit of 6-6.5, recommended by Varlık et al. (1993) and Gülyavuz \& Ünlüsayın (1999) cited in Kilincceker et al. (2009), with the exception for the first sampling moment (13 days). Similar results were reported in a study conducted by Sathivel et al. (2007) during 8 months at $-35{ }^{\circ} \mathrm{C}$, where the uncoated samples showed a $\mathrm{pH}$ of $6.6 \pm 0.1$, glazed samples a pH of $6.5 \pm 0.1$ and samples coated with chitosan a $\mathrm{pH}$ of $6.4 \pm 0.1$.

\subsection{Color parameters}

As is commonly known salmon has natural color variations. For this reason, it was not possible to compare the color match between different coatings, since each sample group was obtained from different salmon fillets. These variations would greatly affect the color parameters during storage, which would invalidate conclusions. Therefore, it was only evaluated the variation of the color parameters for each group of samples - uncoated, glazed and coated samples - over time, separately.

The results for $\mathrm{L}^{*} \mathrm{a}^{*} \mathrm{~b}^{*}$ obtained during the experiment did not present significant variations or any kind of trend.

Fig. 9 shows the variation in perceived color differences of the salmon samples during storage $\left(\Delta E^{*} a b\right)$. A large variability of the values is noticeable, especially for the samples coated with $0.5 \%$ chitosan. This may have been due to the higher color coordinates of the first sample coated with $0.5 \%$ chitosan, which serves as a standard for the remaining time. The samples coated with $1.5 \%$ chitosan were those that showed the most promising results. During storage, these samples showed greater stability presenting, for the majority of time, the lowest values of $\Delta E^{*} a b$, even below the acceptable thresholds of 1.1-2.1 (Ahmad, 2006). For this reason, this coating may be the one that better protects fish color, since this was the coating who caused minor color differences when applied

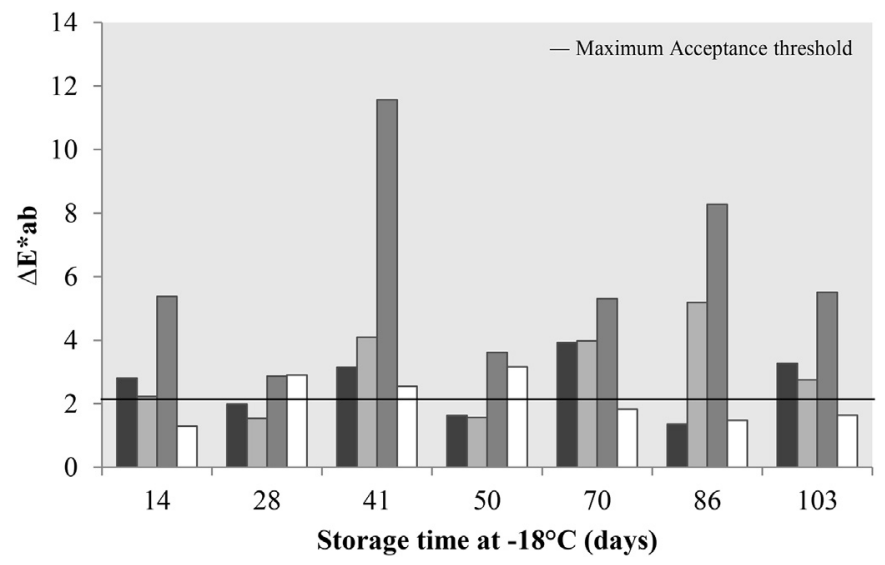

Fig. 9. $\Delta E^{*} a b$ values for salmon samples from the control group ( $\square \mathrm{QS}$ ), glazed with water $(\square \mathrm{Q} 0)$ and coated with $0.5 \%$ chitosan ( $\square$ Q5) and $1.5 \%$ chitosan ( $\square$ Q15) during 103 days of storage at $-18{ }^{\circ} \mathrm{C}$. on frozen salmon samples and consequently being better accepted by consumers.

\section{Conclusions}

One of the main conclusions of this work is the confirmation of the importance of a proper freezing and the relevance of storage control. Indeed, various parameters such as the coating loss, weight loss, drip loss, TVC, TVB-N, and K-value returned very stable due to the protection provided by a correct freezing temperature and a suitable control of its maintenance. Another important finding was the effective protection of the $1.5 \%$ chitosan coating in maintaining the color of salmon and in the control of microbial activity. In fact, the samples coated with $1.5 \%$ chitosan showed less perceptible color differences and provided a consistent protection for both frozen and thawed samples - against microbiological contamination. Thus, this coating is a viable alternative to water glazing, not affecting the perception of quality of consumers.

\section{References}

Ahmad, I. (2006). Protocolos para Restaurações Estéticas Previsíveis. Oxford: Blackwell Publishing Ltd.

Directive 95/149/EC. (1995). Fixing the total volatile basic nitrogen (TVB-N) limit values for certain categories of fishery products and specifying the analysis methods to be used. Official Journal of the European Communities. OJ $\mathrm{N}^{\circ}$ L97, p. 84.

Erikson, U., Beyer, A. R., \& Sigholt, T. (1997). Muscle high-energy phosphates and stress affect K-values during ice storage of Atlantic Salmon (Salmo salar). Journal of Food Science, 62(1), 43-47.

Falguera, V., Quintero, J. P., Jimenez, A., Munoz, J. A., \& Ibarz, A. (2011). Edible films and coatings: structures, active functions and trends in their use. Trends in Food Science \& Technology, 22, 293-303.

Fan, W., Sun, J., Chen, Y., Qiu, J., Zhang, Y., \& Chi, Y. (2009). Effects of chitosan coating on quality and shelf life of silver carp during frozen storage. Food Chemistry, 115(1), 66-70.

FAO. (2012). The state of world fisheries and aquaculture. Rome: Fisheries and Aquaculture Department.

Fellows, P. (2000). Food processing technology: Principles and practice (2nd ed.) Cambridge England: Woodhead Publishing Limited.

Gonçalves, A. A., \& Gindri Junior, C. S. G. (2009). The effect of glaze uptake on storage quality of frozen shrimp. Journal of Food Engineering, 90, 285-290.

International Commission on Microbiological Specifications for Foods (ICMSF). (1986). Microorganisms in foods 2. Sampling for microbiological analysis: Principles and specific applications (2nd ed.). New York: Blackwell Scientific Publications, University of Toronto Press.

ISO 4833. (2003). Microbiology of food and animal feeding stuffs - Horizontal method for the enumeration of microorganisms - Colony-count technique at $30^{\circ} \mathrm{C}$. International Organization for Standardization.

Jacobsen, S., \& Fossan, K. M. (2001). Temporal variations in the glaze uptake on individually quick frozen prawns as monitored by the CODEX standard and the enthalpy method. Journal of Food Engineering, 48, 227-233.

Johnston, W. A., Nicholson, F. J., Roger, A., \& Stroud, G. D. (1994). Freezing and refrigerated storage in fisheries. FAO Fisheries Technical Paper - 340, Rome.

Kilincceker, O., Dogan, I. S., \& Kucukoner, E. (2009). Effect of edible coatings on the quality of frozen fish fillets. LWT - Food Science and Technology, 42, 868-873.

NP 2930. (2009). Produtos da pesca e da aquicultura - Determinação do teor de azoto básico volátil total (ABVT) - Método de Conway. Instituto Português da Qualidade.

Olafsdóttir, G., Martinsdóttir, E., Oehlenschäger, J., Dalgaard, P., Jensen, B. Undeland, I., et al. (1997). Methods to evaluate fish freshness in research and industry. Trends in Food Science and Technology, 8, 258-265.

Pereira, R. N., Souza, B. W. S., Cerqueira, M. A., Teixeira, J. A., \& Vicente, A. A. (2010) Effects of electric fields on protein unfolding and aggregation: influence on edible films formation. Biomacromolecules, 11(11), 2912-2918.

Pinheiro, A. C., Cerqueira, M. A., Souza, B. W. S., Martins, J. T., Teixeira, J. A., \& Vicente, A. A. (2010). Utilização de revestimentos/filmes edíveis para aplicações alimentares. Boletim de Biotecnologia, 18-28.

Rodriguez-Turienzo, L., Cobos, A., Moreno, V., Caride, A., Vieites, J. M., \& Diaz, O. (2011). Whey protein-based coatings on frozen Atlantic salmon (Salmo salar): influence of the plasticiser and the moment of coating on quality preservation. Food Chemistry, 128, 187-194.

Ryder, J. M. (1985). Determination of adenosine triphosphate and its breakdown products in fish muscle by high-performance liquid chromatography. Journal of Agricultural and Food Chemistry, 33, 678-680.

Saito, T., Arai, K., \& Matsuyoshi, M. (1959). A new method for estimating the freshness of fish. Bulletin of the Japanese Society of Scientific Fisheries, 24, 749-750. 
Sathivel, S., Liu, Q., Huang, J., \& Prinyawiwatkul, W. (2007). The influence of chitosan glazing on the quality of skinless pink salmon (Oncorhynchus gorbuscha) fillets during frozen storage. Journal of Food Engineering, 83, 366-373.

Soares, N. M., Mendes, T. S., \& Vicente, A. A. (2013). Effect of chitosan-based solutions applied as edible coatings and water glazing on frozen salmon preservation - a pilot-scale study. Journal of Food Engineering, 119(2), 316-323.
Souza, B. W. S., Cerqueira, M. A., Ruiz, H. A., Martins, J. T., Casariego, A., Teixeira, J. A., et al. (2010). Effect of chitosan-based coatings on the shelf life of Salmon (Salmo salar). Journal of Agricultural and Food Chemistry, 58, 11456-11462.

Vanhaecke, L., Verbeke, W., \& De Brabander, H. F. (2010). Glazing of frozen fish: analytical and economic challenges. Analytica Chimica Acta, 672, 40-44. 